\title{
A geomorphodiversity map of the Soutpansberg Range, South Africa
}

\author{
Edmore Kori $\odot *$, Beneah Daniel Onyango Odhiambo ๑ , Hector Chikoore ๑
}

Department of Geography and Geo-Information Sciences, University of Venda, Thohoyandou, South Africa,

*Edmore.Kori@univen.ac.za

\begin{abstract}
Within the emerging broad science of geodiversity, geomorphological diversity (geomorphodiversity) assesses the form of surface features of a place or region. This paper uses SRTM data and GIS techniques to assess geomorphological diversity of the Soutpansberg range, in Limpopo Province, South Africa. Suitable factors to assess geomorphological diversity were identified as geology, slope position, soil erodibility, landform position, relative heights, insolation, hydrography and ruggedness. Each factor was normalised to five classes by applying natural breaks. All the eight factors were weighted before overlaying. The weighting reveal that respectively, geology, slope and soils carry more weight. Ruggedness, relative height and insolation carry the least weight, in that order. The final geomorphodiversity map reveals that almost half of the Soutpansberg range has high to very high geomorphological diversity. We conclude that factor specific research can add more information to geomorphodiversity research and education.
\end{abstract}

Key words: geomorphological diversity; Soutpansberg; variable; geodiversity; geomorphology

\section{Introduction}

The world is diverse in almost all senses (Gray 2004). The diversity of the physical environment is enormous and is of special interest to geoscientists. Some places are valleys while others are vast expanses of water, like oceans. Other places are open expanses of sands like deserts, while others are undulating and mountainous. With such diversity comes variability within and between the different landscapes. The variability in abiotic ecosystem components is termed geodiversity. Geodiversity can be extrinsic, intrinsic, simpler, broader, defined by scale and or subjective (Panizza 2009). The intrinsic and simpler geodiversity are loosely applied in this paper. The loose application is in the sense that we focus on the diversity within (intrinsic) a mountainous region (simpler). The geodiversity assessment encompasses a wide variety of abiotic components of the mountain region rather than the geology only as defined by Panizza (2009).

Mountainous regions generally experience more precipitation and wind turbulence affecting the geomorphic behaviour of both water and wind (Banta, Cotton 1981, Barry 2008, Peattie 2013, Stoelinga et al. 2013, Sun, Sun 2015). The geomorphic behaviour depends on differences in ground surface characteristics such as roughness, slope, vegetation cover, and soil characteristics (Uzun et al. 2017). The landscape is the manifestation of the interaction between exogenous and endogenous processes shaping the earth's surface (Huggett 2007, Melelli et al. 2017). Therefore, topography is also influenced by geology and elevation. The interactions between the exogenous and endogenous processes produce unique geomorphological landforms. Different geomorphological landforms may occur within the same geographical setting, creating landform diversity, termed geomorphodiversity. The geomorphodiversity of any location on the landscape is a product of all the landforms.

The Soutpansberg range is an outstanding landmark in Vhembe District of Limpopo Province in South Africa. Rising to more than $1600 \mathrm{~m}$ a.s.l on the western side, the mountain range makes a picturesque of geomorphology in the region. Its east-west orientation creates a huge and unique earth atmosphere interaction in the region. The orientation of the mountain range creates a landscape that influences rainfall distribution due to its effect on both large and small scale atmospheric circulation systems (Ka- 
banda 2004, Oettli, Camberlin 2005, Smith 2007, Barry 2008, Zardi, Whiteman 2013, Sun, Sun 2015, Rodrigues et al. 2016). Moist south easterly prevailing winds from the Indian Ocean are forced to rise over the southern scarp of the range (Kabanda 2004) resulting in rainfall on the south facing slopes while the air dissipates in valleys, creating dryness. This creates an interesting scenario for geomorphological processes, and hence, geomorphodiversity.

The topographic setting of the mountain range gives rise to orographic rainfall and wind patterns that create a diversity of microclimates (Berger et al. 2003, Kephe et al. 2016). The geological substrate and the geomorphological processes create the basis for the weathering activity and the soil formation that create unique abiotic settings (Musila et al. 2005). Consequently, the geomorphodiversity assessment of the landscape is a crucial step in the study of ecosystems and ecosystem services (Melelli et al. 2017) provided by the Soutpansberg range.

\section{Background}

Geomorphodiversity, which falls within the broad geosciences field of geodiversity, is a critical and specific assessment of form or surface features of a defined place on Earth (Demek et al. 2011). In the field of Geomorphology, geodiversity may be interchanged with the term geomorphodiversity (Panizza 2009). Geomorphodiversity is the range, or diversity, of the landscape components of a defined area (Melelli et al. 2017). For the purposes of clarity, we use the term geomorphodiversity as the range and complexity of form or surface features of a defined landscape (Panizza 2009, Demek et al. 2011, Melelli et al. 2017).

The term geodiversity emerged during the 1990s to describe variety within the abiotic nature (Gray 2004, Panizza 2009, Gray et al. 2013, Brilha et al. 2018). This emergence came from the backdrop of the misconception and bias that led to the view that biodiversity and conservation applied only to the biotic components of the natural systems (Jerie et al. 2001, Milton 2002). The misconception is an aftermath of the 1992 Rio Earth Summit (Panizza 2009, Brilha et al. 2018) where the biodiversity concept had dominated. Thereafter, the term geodiversity was coined and was generally used in geological and geomorphological conservation studies in Australia (e.g. Sharples 1995). However, the definition of geodiversity is not yet consistent.

The early definition of geodiversity considers the geological (bedrock), geomorphological (landform) and soil features, assemblages, systems and processes (Sharples 1993, Sharples 1995). Gray (2004) defined geodiversity as the natural range (diversity) of geological (rocks, minerals, fossils), geomorphological (land form, processes) hydrological and soil features. It includes their assemblages, relationships, properties, interpretations and systems. Zwolinnski (2004) reprised the definition thus: geodiversity is the natural range (diversity) of the landscape and includes geological (bedrock), geomorphological (landform) and soil features, assemblages, systems and processes. In short, Sharples et al. (2018) describe geodiversity as the quality of the abiotic natural resources that need to be conserved. Nonetheless, the term is now used around the world and is now internationally recognised (Brilha et al. 2018).

Although now internationally recognised, geodiversity is still widely not considered in policies and processes that foster sustainable development (Brilha et al. 2018). Consequently, little progress has been made in its quantitative assessment and application (Panizza 2009, Brilha et al. 2018, Zwoliński et al. 2018). Recognition of geodiversity in ecosystem assessment remains low, and it is poorly integrated within the ecosystem approach despite its fundamental underpinning of many key ecosystem functions and services. Geodiversity underpins and delivers many vital ecosystem services, informs their management and is an important element of natural capital (Gray et al. 2013). The crucial challenge for geoscientists is how to develop the science of geodiversity and its application to establish its fundamental components for scientifically acceptable mapping and assessment.

Sensu stricto, the ecosystem includes abiotic and biotic elements interacting as functional units. The geodiversity science approach recognises the role of abiotic resources in supporting biodiversity and the need for integrated ecosystem management (Gray et al. 2013, Melelli et al. 2017). However, methods and techniques used for assessing abiotic and biotic elements are not always comparable (Matthews 2014). Nonetheless, it is a fact that biodiversity is a function of the geodiversity of the area. Hence, geoscientists consider the geodiversity approach as novel that it can bring the abiotic components of the ecosystems to the fore of nature conservation, and, probably, at par with biodiversity.

Melelli et al. (2017) identify three main components involved in the geodiversity approach. The components are the geological parameters, the geomorphological processes and the landforms as well as the resulting soil types. Brilha et al. (2018) simplify the characterisation of geodiversity by answering three basic questions - what? why? how? "What?" guides the identification of the types of geodiversity elements present in an area and its spatial distribution. "Why?" directs the goals for its characterisation and mapping. "How?" directs the choice of methods 
and criteria for the geodiversity characterisation and assessment. The methods are guided by the geodiversity elements available and the reason for their characterisation. Therefore, relatively subjective geodiversity assessment methods have emerged.

The geodiversity assessment methods may be classified into two broad categories of qualitative and quantitative. While the qualitative approach is descriptive, the quantitative approach uses numerical values to indicate diversity. The quantitative assessment of geodiversity using GIS and map algebra is emerging as a powerful tool in geodiversity mapping (Brilha et al. 2018, Zwoliński et al. 2018). Map algebra is used to compile the results of partial assessments of geodiversity elements through algebraic and logic operations and functions using raster or vector spatial data. The cartographic output of the procedures can be a complete geodiversity map or partial - geomorphological, lithological, pedological, hydrological, or palaeontological diversity - indices maps.

This paper uses GIS and map algebra to produce a geomorphodiversity map of the Soutpansberg range of South Africa. A geomorphodiversity map focuses on landforms and morphological diversity. Landforms define the diversity of the geomorphological components of the landscape and form a central pillar in geomorphodiversity (Thomas 2012, Melelli et al. 2017). A geomorphodiversity rather than a geodiversity approach is adopted because it recognizes, evaluates, and promotes the landscape diversity of an area (Melelli et al. 2017).

\section{Study area}

The Soutpansberg, formerly Zoutpansberg, means Salt Pan Mountain in Afrikaans. The mountain range was formed some 1800 million years ago by an east-west trending asymmetrical rift or half-graben along the Palala Shear Belt (Berger et al. 2003). It is a prominent quartzite mountain range in the northern part of South Africa, Limpopo Province in Vhembe District. Figure 1 shows that the Soutpansberg stretches for approximately $210 \mathrm{~km}$ from Kruger National Park's Punda Maria gate in the east to Vivo in the west. The eastern end of the range is close to the Zimbabwe-Mozambique-South Africa border. The mountain range's highest peak is on its western side, reaching the elevation of $1,748 \mathrm{~m}$ a.s.l. The widest part is a $60 \mathrm{~km}$ wide north-south axis while the narrowest is $15 \mathrm{~km}$ (Berger et al. 2003).

Soutpansberg receives rainfall between October of the previous year and April of the following year. Average rainfall ranges from as low as around $350 \mathrm{~mm}$ on the northern slopes, $550 \mathrm{~mm}$ in the east to 2,000 $\mathrm{mm}$ along the central southern slopes (Berger et al. 2003, Kabanda 2004, Mostert 2006). Winds exit the mountain range at Waterpoort, creating a rain shadow effect where rainfall can be as low as $340 \mathrm{~mm}$ per year while Entabeni, in the central sections of the mountain, can record as high as 2,000 mm of annual precipitation (Kabanda 2004). The driest areas are the northern slopes as well as valley floors bordered on either side by mountain ridges.

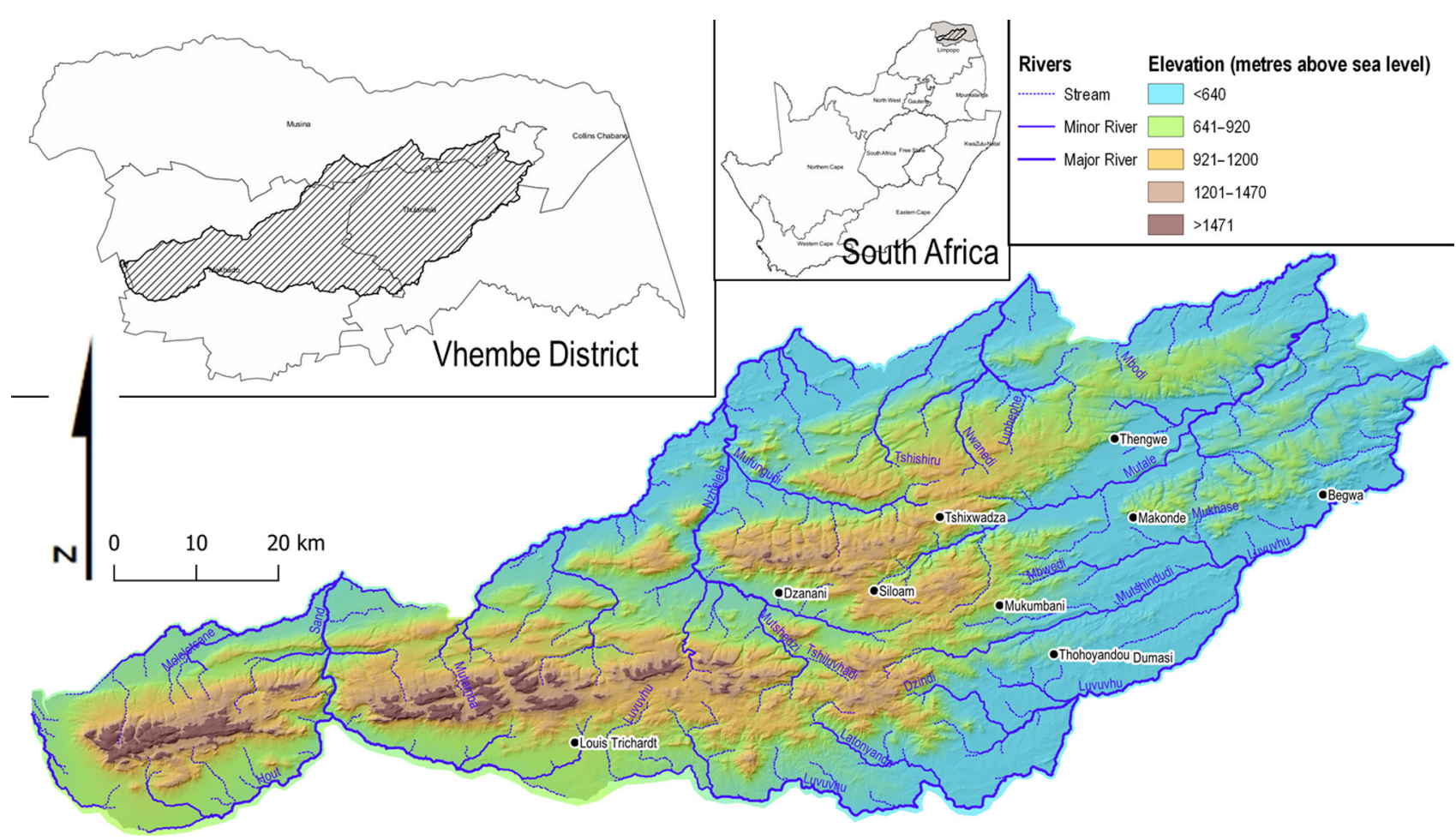

Fig. 1. Soutpansberg Range indicating location in South Africa and Vhembe District (DEM Source: National Geo-Spatial Information, 2016) 
The mountain forms a geological unit with the Makgabeng Plateau and Blouberg Mountain to the west of Vivo (Berger et al. 2003). The Soutpansberg rocks rest on gneisses of the Limpopo Belt and Bandelierkop Complex. Along the eastern and most of the northern margin the Soutpansberg outcrops are tectonically juxtaposed against rocks of the Karoo Super group (Brandl 2003). The range has the best exposed Rift Sequence in South Africa. The Soutpansberg Group rocks are the most intensively block-faulted sequence in the country (Berger et al. 2003). The 3-4 km thick Basalt unit at the base of the Soutpansberg Group is the thickest uninterrupted volcanic sequence in South Africa.

The Soutpansberg range is part of the Vhembe Biosphere Reserve (VBR) recognised by UNESCO since 2009. VBR is a special area for the conservation of a biodiverse environment and promotion of sustainable development. Covering an area of 6,800 $\mathrm{km}^{2}$, the mountain range has been widely studied. The studies covered fields such as biology (Foord et al. 2008, Hahn 2010, Taylor et al. 2013, Grey et al. 2017) climatology (Kabanda 2004, Kabanda, Munyati 2010, Nenwiinia, Kabanda 2013, Kephe et al. 2016), ecology (Mostert 2006, Kirchhof et al. 2010, Foord et al. 2015), and on geology (Berger et al. 2003). Kabanda (2004) describes the Soutpansberg range as a complex terrain of ridges with various peaks, separating vast areas of valley systems. Consequently, the mountainous region has special hydrological, geological and erosional processes. This paper adds the geomorphological analysis of the Soutpansberg region to the library of research on the VBR.

\section{Materials and Methods}

\section{Data Needed and Sources}

Eight factors are considered for the geomorphodiversity assessment of the Soutpansberg. The factors are derived with guidance from Thomas (2012), Najwer, Zwoliński (2014) and Melelli et al. (2017). The guidance limits the input data to variables linked to the evolution of the physical landscape only. The factors are insolation, hydrography, geology, soils, slope position, landforms, ruggedness and relative height.

Except soils, hydrography and geology, the other five factors were derived from the $30 \mathrm{~m}$ raster size SRTM DEM obtained from National Geo-Spatial Information (NGI). The derivations were done in SAGA GIS. Hydrography systems shape files were obtained from Department of Water Affairs, Forestry and Fisheries (DWAFF). However, for line density calculation, we used river systems derived from the DEM. The fluvial channels were extracted through semi-automatic calculations in SAGA GIS and the Strahler's hierarchical classification of channels was applied at level seven (Araujo, Pereira 2018). This was necessary in order to include waterways that are not captured in the DWAFF system. Geological data was downloaded from South African Geosciences online database. Harmonized World Soil Database (HWSD v 1.21) layer was obtained from The International Institute for Applied Systems Analysis (IIAS) online database.

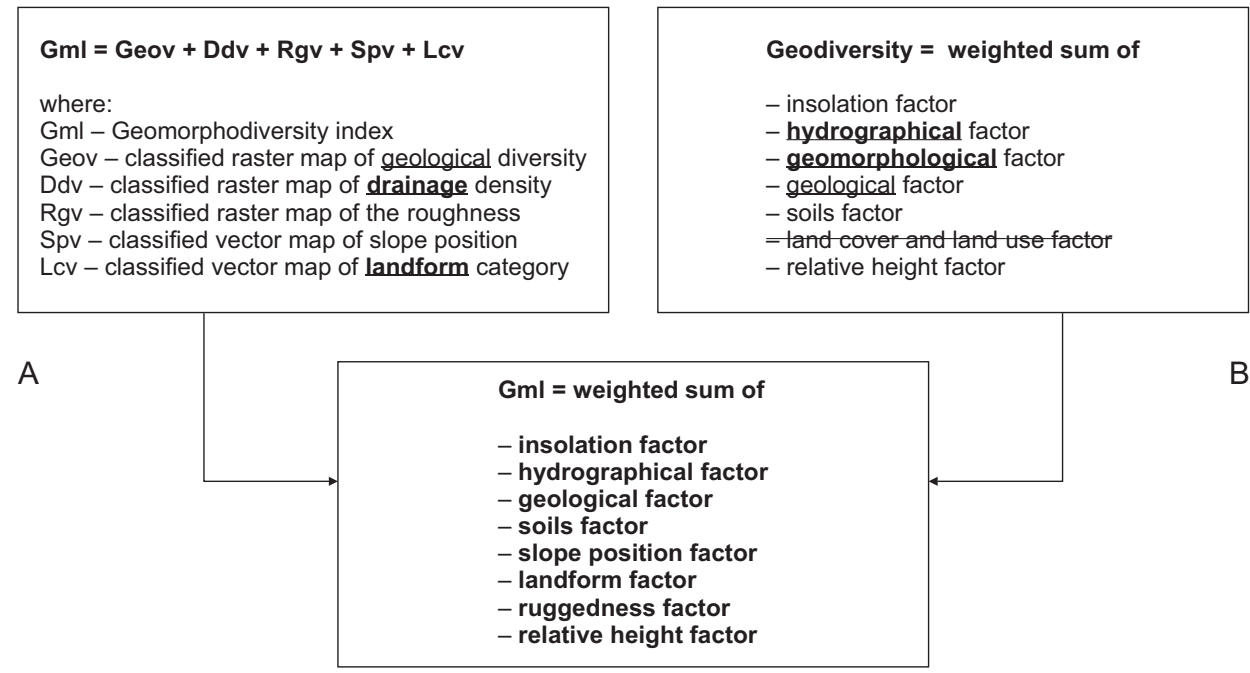

Fig. 2. Geomorphological diversity factors selection guide (underlined factors appear in both methods and are adopted without change. Bold and underlined factors are related and were merged. The crossed-out factor is not considered) A - Melelli et al. 2017, B - Najwer, Zwoliński 2014 


\section{Data processing and analysis methods}

Input variables adapted the Geomorphodiversity Index (GmI) (Melelli et al. 2017) and the Geodiversity assessment criteria proposed by Najwer, Zwoliński (2014) as shown in Figure 2. The geology factor appears in both methods and is treated without any alterations as it is treated in the same manner in both $\mathrm{GmI}$ and geodiversity assessments. Drainage density from $\mathrm{GmI}$ is incorporated into the hydrographical factor since they are related but not treated in the same manner by the different methods. Merging the two improves the quality of hydrographical representation. The geomorphological factor is incorporated into the landform category factor. Land use and land cover change is excluded in the final $\mathrm{GmI}$ because the focus of this paper is on natural factors only. Thus, a weighted sum of eight factors analyses the geomorphodiversity of the Soutpansberg range.

\section{The factor maps}

This analysis comprised of eight factors adapted from Melelli et al. (2017) and Najwer, Zwoliński (2014). It is important to point out that except for the geology factor map, all the other factor maps went through two processing stages. The first stage is derivation from the raw data. The second stage is normalisation using natural breaks (Jenks 1967). The normalisation used the reclassify tool of ArcGIS 10.7 to create five classes for each factor. One is the lowest while five is the highest diversity class.

The first factor to be derived from the DEM is insolation. The insolation factor represents solar radiation across a landscape or a specific location. It is derived from DEM based on methods from the hemispherical viewshed algorithm.

Ruggedness, the second factor, was calculated using the topographic roughness index in SAGA GIS. The roughness factor expresses the amount of elevation difference between adjacent cells of a DEM. The landscape roughness is a measure of the irregularities of a topographic surface.

The third and fourth factors are slope position and landform position, respectively. The slope position factor classifies the landscape into cliffs, scree slopes, transportation mid-slopes, foot slopes and open valleys (Jenness 2006). The landform position factor classifies the landscape into morphological classes steep sided ridges, flat-topped plateaux, gentle plains, open slopes and river channels (Jenness 2006). Both were obtained using the Topographic Position Index (TPI) in SAGA GIS. The TPI is defined as the difference between a cell elevation value and the average elevation on a neighbouring area around the cell. The TPI is computed considering a $300 \mathrm{~m}$ radius circle neighbourhood in tandem with the $30 \mathrm{~m}$ resolution of the DEM.

The fifth factor is relative heights which shows the diversity of relative (local) heights, which reflects the energy of the relief (Zwoliński 2009). Relative height is a measure of elevation of a place in relation to its surroundings, not the sea level. Therefore, relative height takes away the insignificance an elevation point may have as compared to the rest of the world. This step localises points in terms of significance in the landscape.

The remaining three factors were not derived from DEM. The geology factor map was created in ArcGIS from the geology shape files obtained from the South African Geosciences online database. Houshold, Sharples (2008) suggested the inclusion of the interrelated character of assemblages in geodiversity assessment. In line with that we considered lithological diversity as well as hardness in the production of the geology factor. The attributes (in the attribute table) of each polygon in the geology shape file indicate the presence of a dominant rock type plus the presence of up to four other rocks. Therefore, lithological diversity was assessed considering the number of lithologies each polygon had. One represented one rock type while five represented five rock types in the polygon.

Lithological diversity was merged with rock hardness classes as shown in Table 1. The rock hardness class was decided from the main rock, defined in the attribute table as lithol. Lithological diversity and rock hardness were combined using the raster calculator of ArcGIS to produce the geology factor. The geology factor was normalised into five categories following natural breaks (Jenks 1967) using the reclassification tool in ArcGIS.

The soil factor map was produced based on soil erodibility (K). Soil erodibility is a characteristic of choice due to the way erosion shapes landscapes. The $\mathrm{K}$ factor is important because it is the intrinsic characteristic of a soil to be eroded (Karydas et al.

Table 1. Rock hardness classes (5 indicates highest hardness)

\begin{tabular}{lll}
\hline \multicolumn{1}{c}{ Igneous } & \multicolumn{1}{c}{ Metamorphic } & \multicolumn{1}{c}{ Sedimentary } \\
\hline Granite (5) & Gneiss* (3) & Sandstone (4) \\
Norite (4) & Marble (3) & Arenite (4) \\
Dolerite (4) & & Conglomerate (3) \\
Epidiorite (4) & & Shale (3) \\
Basalt (4) & & Siltstone (3) \\
Tuff (3) & & Mudstone (2) \\
& & Coal (2) \\
& & Calcrete (1) \\
\hline
\end{tabular}

${ }^{*}$ Gneiss is classified as medium hardness because of the wide range of mineralogy 
Table 2. Soil erodibility

\begin{tabular}{lcccc}
\hline \multirow{2}{*}{ Soil Type } & $\begin{array}{c}\text { Total } \\
\text { sand }\end{array}$ & $\begin{array}{c}\text { Total } \\
\text { silt }\end{array}$ & $\begin{array}{c}\text { Total } \\
\text { clay }\end{array}$ & Erodibility (K) \\
\cline { 2 - 4 }$[\%]$ & & & \\
\hline Eutric regosols & 69 & 19 & 12 & 0.073 \\
Ferric luvisols & 65 & 18 & 17 & 0.048 \\
Eutric leptsols & 50 & 20 & 30 & 0.023 \\
Haplic lixisols & 63 & 15 & 22 & 0.035 \\
Calcaric arenosols & 89 & 6 & 5 & 0.190 \\
Lithic leptosols & 43 & 29 & 28 & 0.024 \\
Ferralic arenosols & 89 & 5 & 6 & 0.046 \\
Calcic luvisols & 63 & 16 & 21 & 0.037 \\
Calcaric cambisols & 35 & 37 & 28 & 0.025 \\
Eutric plinthosols & 65 & 18 & 17 & 0.048 \\
Chromic cambisols & 42 & 26 & 32 & 0.021 \\
Rhodic nitrisols & 27 & 24 & 49 & 0.010 \\
Haplic acrisols & 9 & 6 & 15 & 0.056 \\
Eutric cambisols & 45 & 31 & 24 & 0.031 \\
\hline
\end{tabular}

2013). Soil erodibility has a significant influence on landform and landscape development. Therefore, it is reasonable to use it in quantifying geomorphic diversity. The K factor was calculated using a formula by Bouyoucos (1935):

$$
\text { Erodibility }(\mathrm{K})=[(\text { sand }+ \text { silt }) /(\text { clay })] / 100 \text {. }
$$

Though there are other formulae such as USLE (Wischmeier, Smith 1978) and SLEMSA (Elwell 1978) that use different parameters to calculate the $\mathrm{K}$ factor, Bouyoucos' method was chosen because it has proved to efficiently match field data (Anache et al. 2015, Marques et al. 2019) in addition to its simplicity to use in a GIS. Therefore, the $\mathrm{K}$ factor was the focus in rasterising the soil shape file. The resultant raster layer was then reclassified according to natural breaks (Jenks 1967).

The last factor map is for the hydrography. We used a combination of the hydrography elements proposed by Najwer, Zwoliński (2014) and those used by Melelli et al. (2017). The former did not include drainage density in their calculations. Therefore, we use lakes, rivers, Topographic Wetness Index (TWI), drainage density, springs and pans. Pans are treated in the same manner as lakes. They are assessed based on shoreline development ratio (DL). It is important to include both rivers as presented by Najwer, Zwoliński (2014) and drainage density as presented by Melelli et al. (2017) because the two consider different aspects of rivers. Najwer, Zwoliński (2014) assessed slope while Melelli et al. (2017) assessed stream occurrence.

\section{Final geomorphodiversity map}

The final geomorphodiversity map is a weighted sum overlay of the eight factor maps. The Multi-Criteria Evaluation (MCE) using the Analytic Hierarchy Process (AHP) was employed to calculate relative weights for each factor map. This is important to consider the potential influence of each factor on the overall geomorphological diversity of the Soutpansberg. The MCE was done online using pairwise comparisons.

\section{Results and Discussion}

\section{Factor maps}

Each factor map went through the stages presented in the methodology section. The final map for each

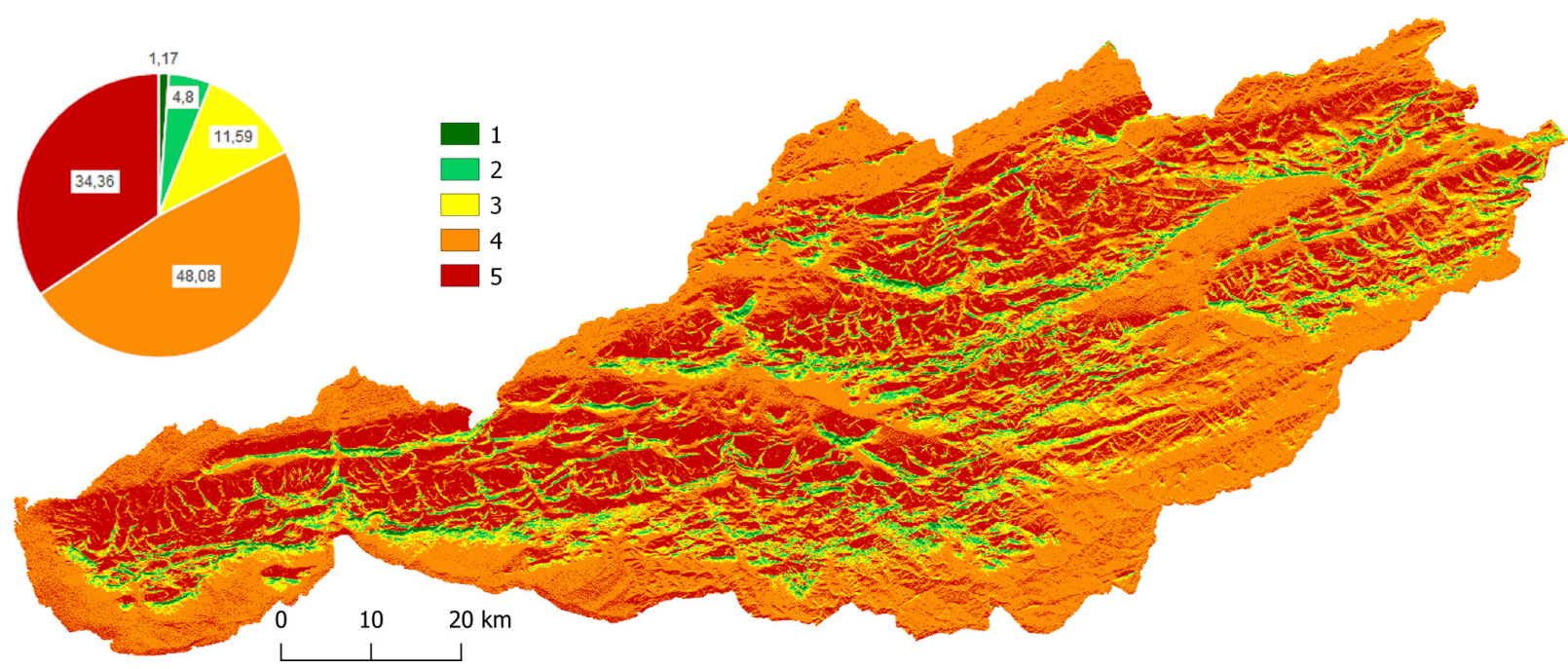

Fig. 3. Soutpansberg total insolation

1 - very low geodiversity, 2 - low geodiversity, 3 - medium geodiversity, 4 - high geodiversity, 5 - very high geodiversity; the numbers on the pie chart are expressed as a percentage 


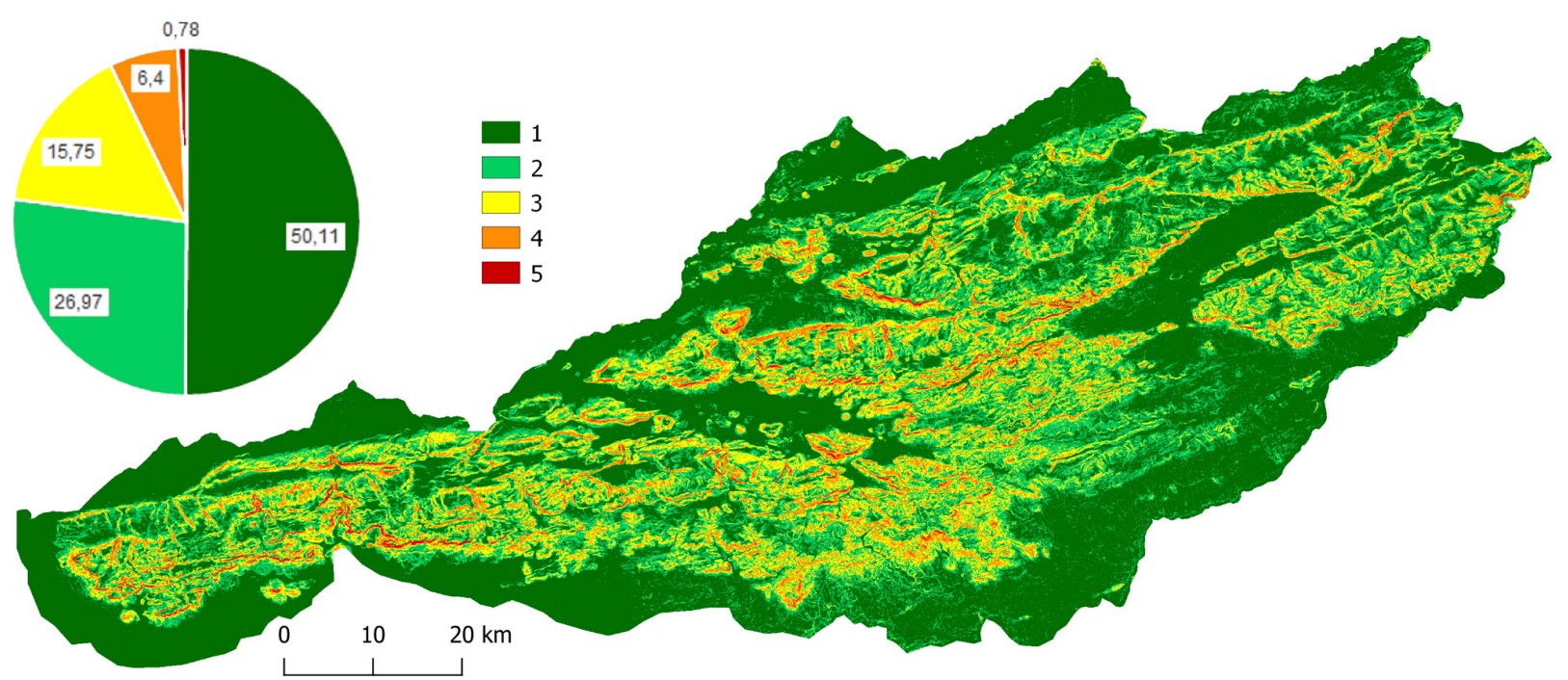

Fig. 4. Soutpansberg ruggedness

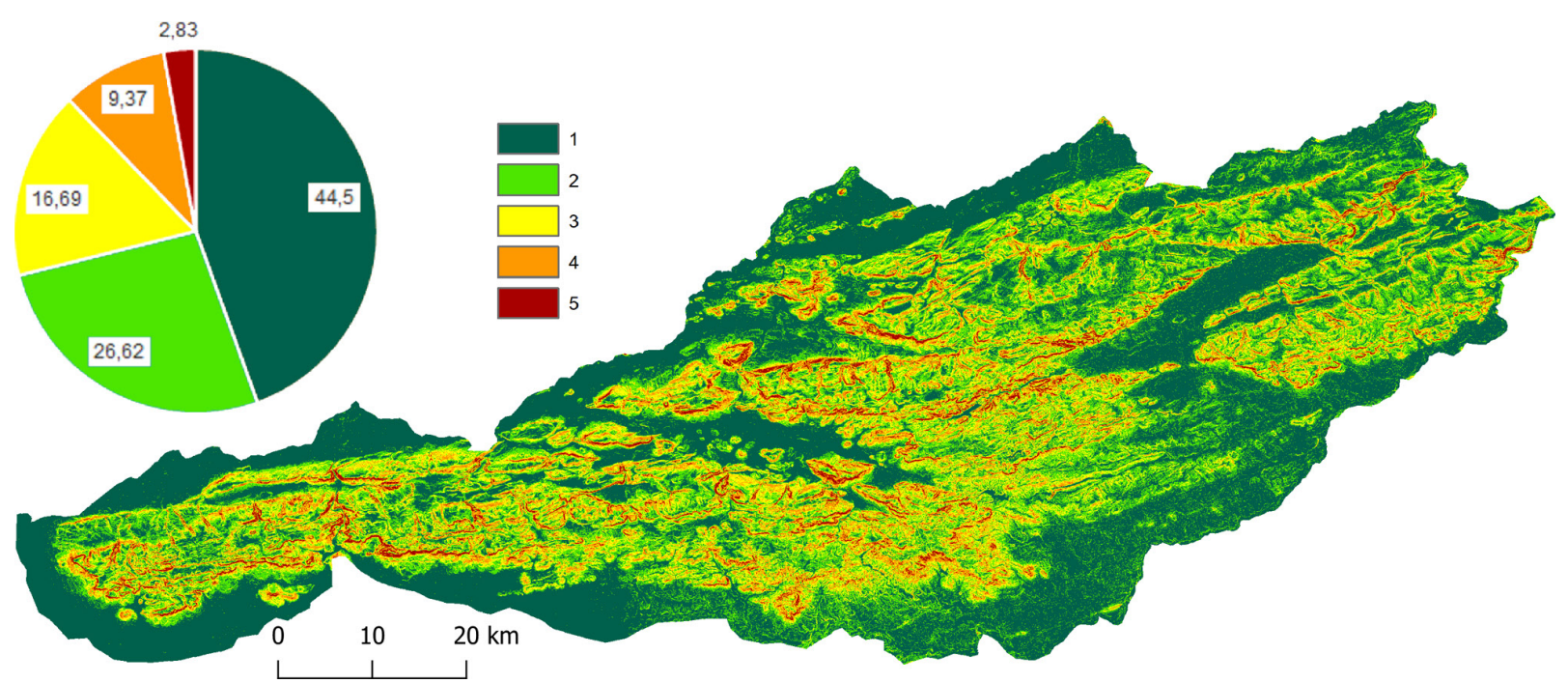

Fig. 5. Soutpansberg slope positions

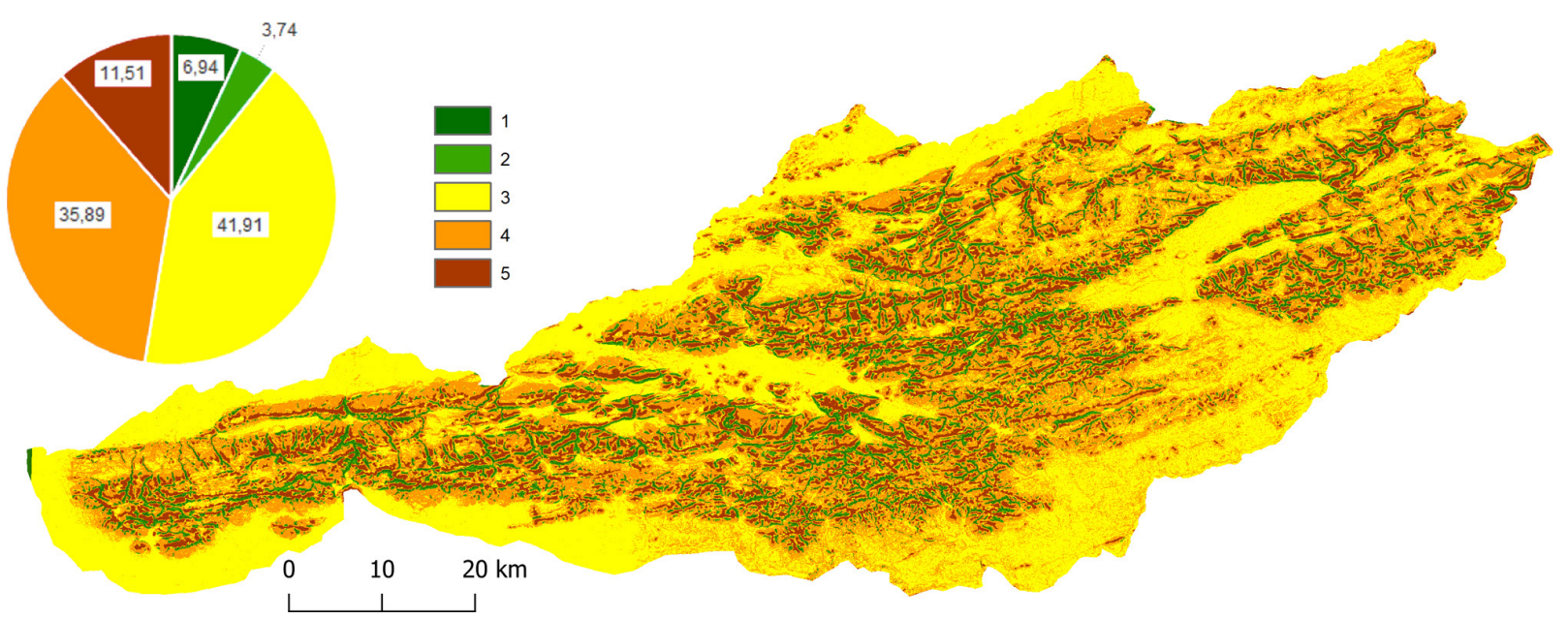

Fig. 6. Soutpansberg landform position

1 - very low geodiversity, 2 - low geodiversity, 3 - medium geodiversity, 4 - high geodiversity, 5 - very high geodiversity; the numbers on the pie chart are expressed as a percentage 
factor would then be reclassified to five classes using natural breaks (Jenks 1967). The classes are presented in different colours. Green represents the lowest values while red represents the highest values.

Insolation factor map shows that the Soutpansberg range experiences high to very high insolation. Figure 3 reveals that over $80 \%$ of the range experiences class four and five total insolation. The areas receiving such insolation coincide with the highest elevation (above $1200 \mathrm{~m}$ a.s.l) and low-lying areas below $640 \mathrm{~m}$ a.s.l. The areas between 640 and $1200 \mathrm{~m}$ a.s.l receive less total insolation probably due to the shading effect of the high elevation zone. This observation is because most of the parts of the mountain range falling in classes one to three are on south facing slopes. The Soutpansberg region is in the southern hemisphere, therefore, aspect plays an important role in determining total insolation.
Ruggedness factor map shows that over $75 \%$ of the Soutpansberg range has low to very low ruggedness. Figure 4 shows that the areas below $920 \mathrm{~m}$ a.s.l have low to very low ruggedness. These areas are found along the mountain edges and river valleys. It should be noted that the Soutpansberg range is the major source of five major river systems of Vhembe District.

A significant part of the range is occupied by settlements and agricultural activities. South facing slopes constitute the famous Levubu River valley. Various forestry activities dominate this region, hence most natural forests have been cleared for plantations. The middle section along Nzhelele river is ocupied by communal settlements which are rapidly expanding. Many houses are now built on slopes of over $15^{\circ}$.

Slope Position factor map reveals the dominance of river valleys. Figure 5 shows that cliffs occupy just about $3 \%$ of the mountain range. The class five slopes

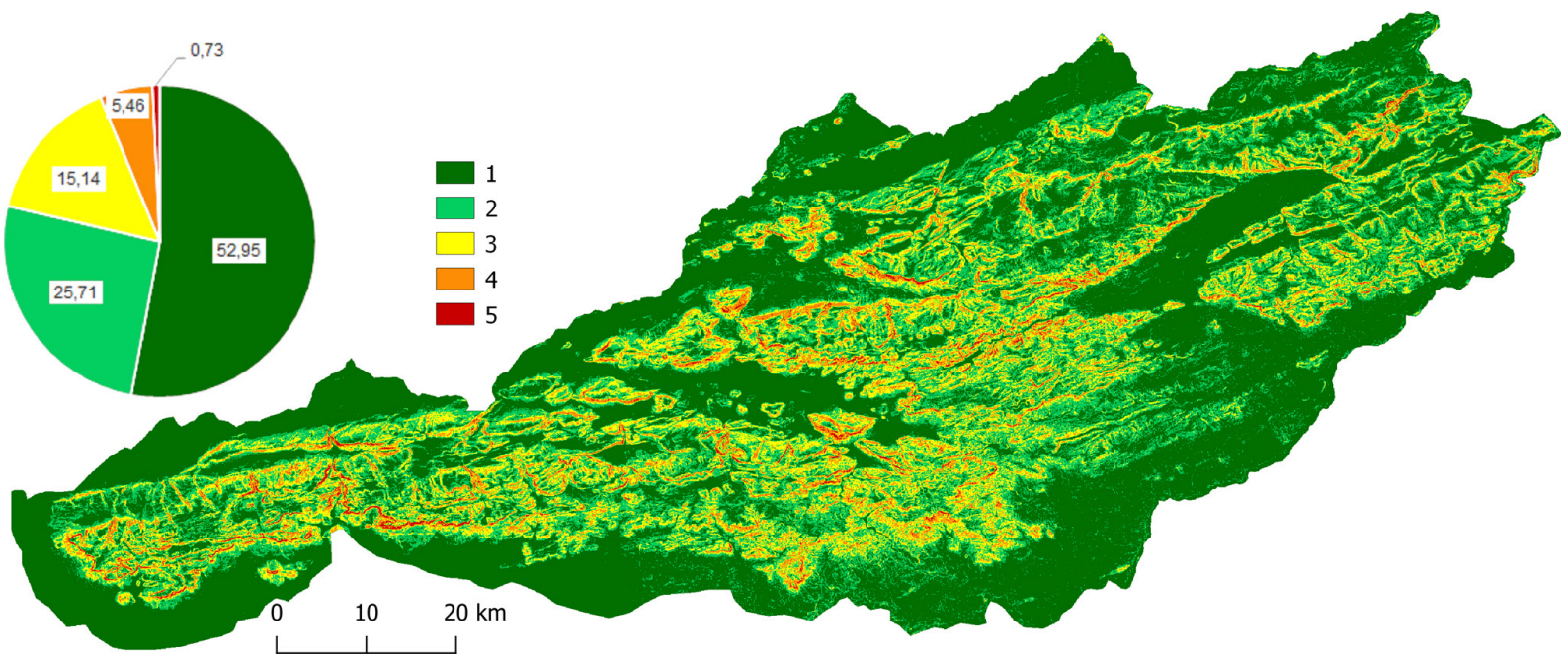

Fig. 7. Soutpansberg relative height

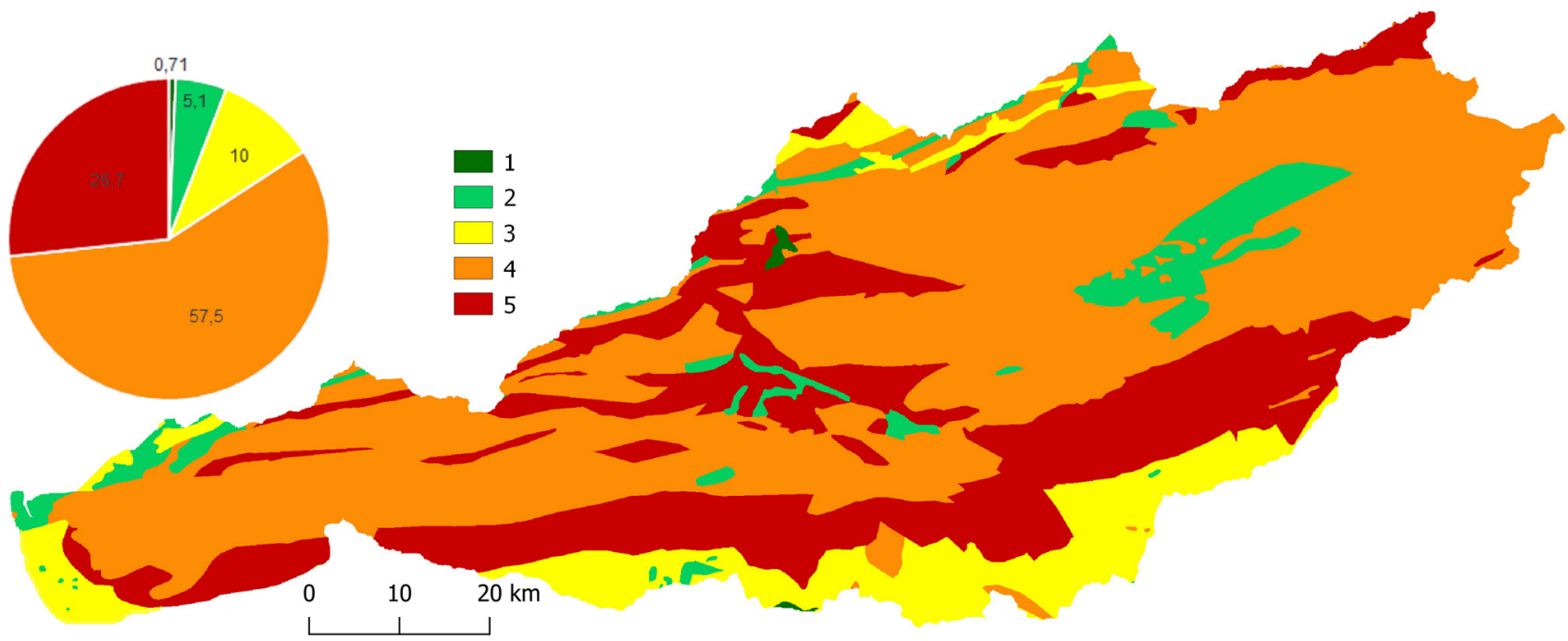

Fig. 8. Soil factor

1 - very low geodiversity, 2 - low geodiversity, 3 - medium geodiversity, 4 - high geodiversity, 5 - very high geodiversity; the numbers on the pie chart are expressed as a percentage 
are found in high elevation places in the central parts of the range. The role of water related denudational processes also come into play as the mountain is a source of five major rivers in Vhembe District. No wonder foot slopes and open valleys occupy over $70 \%$ of the range.

Landform position factor classified the landscape into morphological classes. Figure 6 reveals the dominance of gentle plains in the Soutpansberg range, occupying more than $40 \%$ of the range. River channels occupy the least space as they are overshadowed by the gentle plains and flat-topped plateaux.

Relative height factor reveals the interplay of many factors. This factor strongly correlates with slope, ruggedness and landform position factors. Relative heights as shown in Figure 7 reveal the dominance of gentle plains, flat topped plateaux as well as open valleys. This is an indicator of little local differ- ences in elevation between cells. Again, this is a good indicator of long term denudation on the landscape.

The geology factor shows the dominance of rock hardness with hard and very hard rocks occupying over $80 \%$ of the range. The rocks are predominantly igneous as shown in Figure 8. Granite is the only one in class five and occupies over a quarter of the mountain range.

The soil factor shows the erodibility of the soils found in the Soutpansberg region. Figure 9 shows that over $70 \%$ of the range has moderate to below moderately erodible soils. Very highly erodible soils occupy the least area, mainly along the middle section of the southern edge of the range.

The hydrography factor shows the interplay of high elevation areas, waterways and open valleys. High hydrography represents large water bodies found in the mountain range as shown in Figure 10. These,

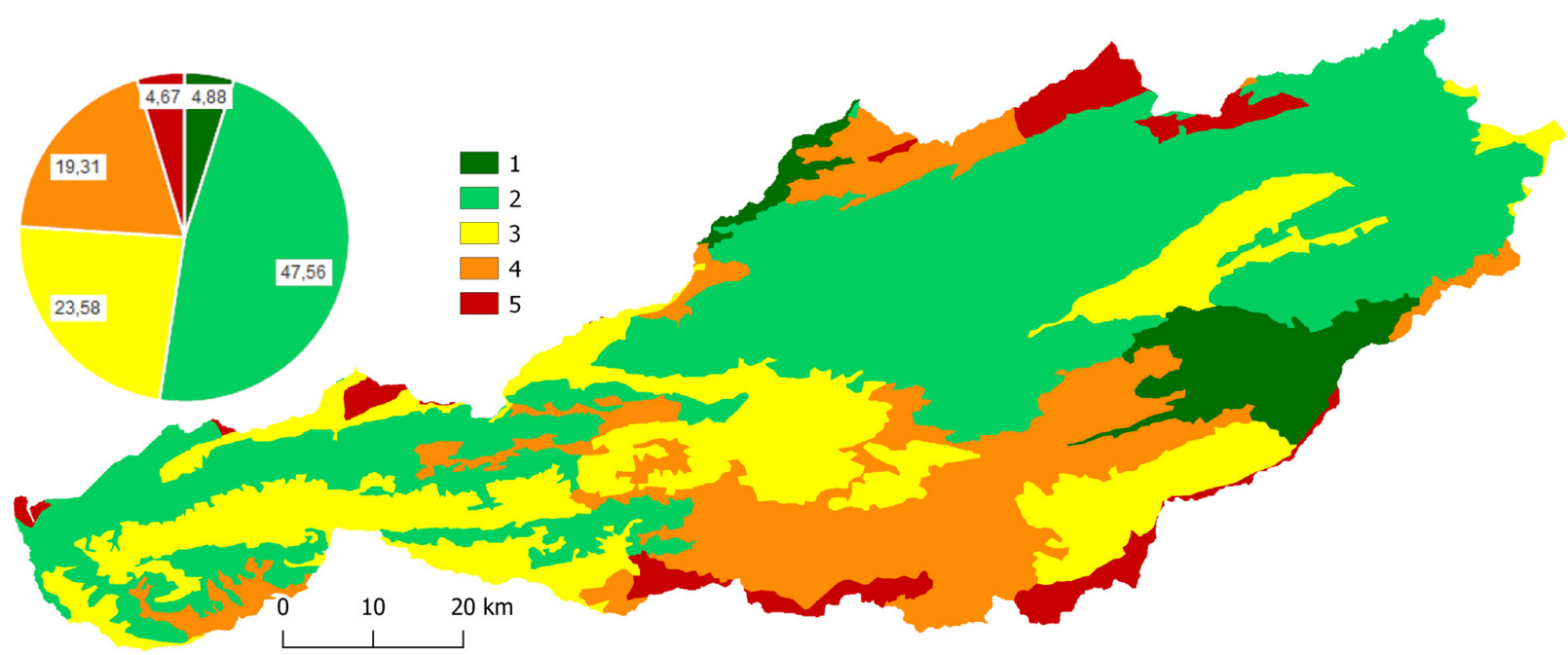

Fig. 9. Geology factor

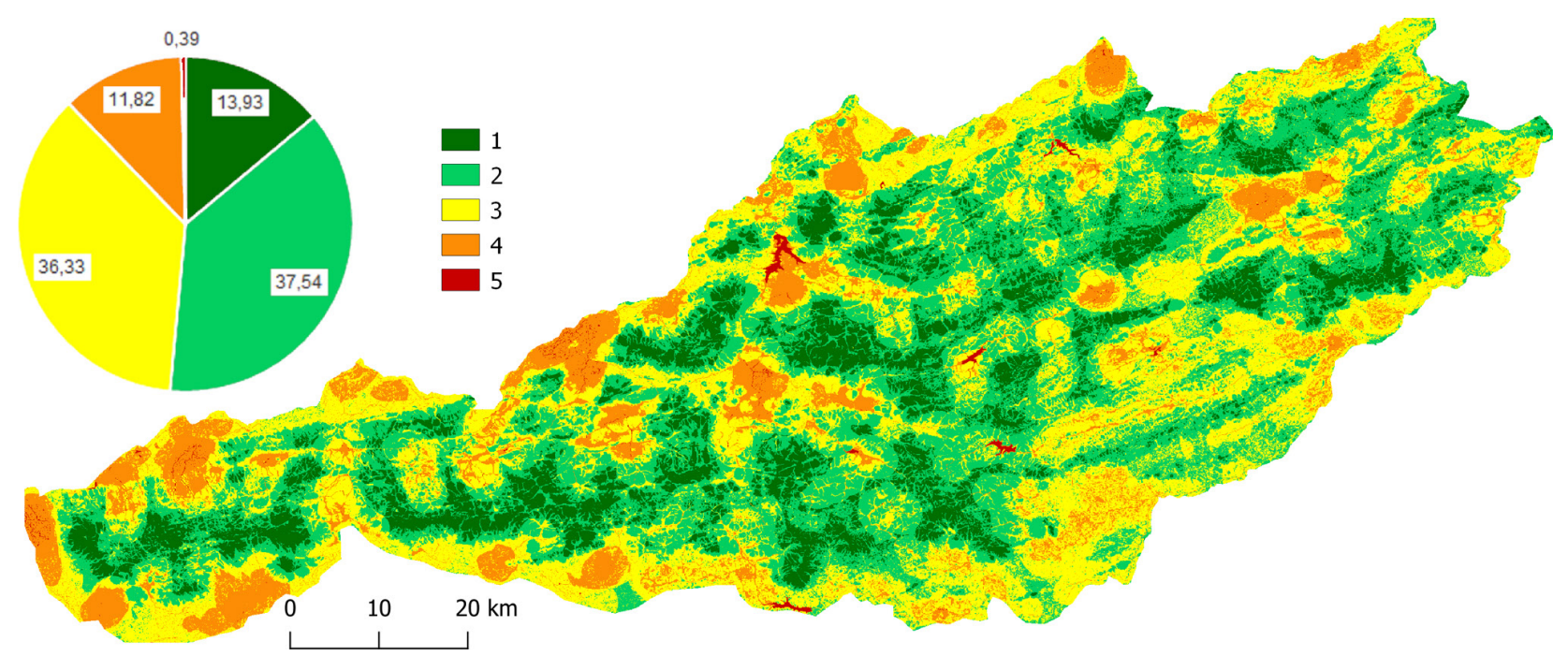

Fig. 10. Hydrography factor

1 - very low geodiversity, 2 - low geodiversity, 3 - medium geodiversity, 4 - high geodiversity, 5 - very high geodiversity; the numbers on the pie chart are expressed as a percentage 
though, occupy less than $1 \%$ of the range. However, the mountain range has a significant amount of water ways that may not necessarily have a high TWI in comparison with dams and lakes. These occupy close to $12 \%$ of the mountain range area. However, just over $50 \%$ of the range has very little to little observable hydrographical features. This explains why the region is a water scarce area.

Before overlaying the eight factors to produce the overall geomorphological diversity of the range, we did a factor ranking by Multi-Criteria Evaluation (MCE) using the Analytic Hierarchy Process (AHP). Table 3 shows that geology, slope and soils carry the highest weight, in that order. Conversely, ruggedness, relative height and insolation carry the least weight, in that order.

The ranking is sensible because geology plays a major role in geomorphological processes. Rocks determine the type of soils, rates of weathering and vegetation growth as well as groundwater systems in an area. Slopes on the other hand influence material movement. Soils characteristics determine erosion

Table 3. Factor Ranking

\begin{tabular}{|c|c|c|c|c|c|}
\hline \multirow{2}{*}{\multicolumn{2}{|c|}{ Category [\%] }} & \multirow{2}{*}{ Priority [\%] } & \multirow{2}{*}{ Rank } & \multirow{2}{*}{\multicolumn{2}{|c|}{$\frac{(+) \quad(-)}{[\%]}$}} \\
\hline & & & & & \\
\hline 1 & Slope & 24.7 & 2 & 11.8 & 11.8 \\
\hline 2 & Geology & 41.7 & 1 & 31.9 & 31.9 \\
\hline 3 & Hydrography & 8.8 & 4 & 3.8 & 3.8 \\
\hline 4 & Soil & 13.3 & 3 & 7.4 & 7.4 \\
\hline 5 & Ruggedness & 3.0 & 6 & 1.2 & 1.2 \\
\hline 6 & Insolation & 2.4 & 8 & 1.0 & 1.0 \\
\hline 7 & Relative height & 2.6 & 7 & 0.9 & 0.9 \\
\hline 8 & Landforms & 3.5 & 5 & 1.3 & 1.3 \\
\hline
\end{tabular}

Consistency Ratio $=8.7 \%$. and vegetation growth. All these factors have a huge impact on geomorphological processes, and hence geomorphological diversity.

The final geomorphological diversity map in Figure 11 reveals the variable strong influence of geology, slope and soils. The factors show different influences in different places. The very high geomorphological diversity shown in the south facing slopes show the strong influence of soils. This is the region with moderate, high and very highly erodible soils. Slope reveals its strongest influence in the edges of the south facing side of the range. This region is dominated by foot slopes and open valleys. Geology exercises its dominance in the western regions of the range. The region has high elevations and supported by hard rocks with thin soils.

\section{Concluding remarks}

The Soutpansberg range is a significant landmark in Vhembe District of South Africa. The geomorphological diversity assessment considered eight factors. The factors include geology, slope position, soil erodibility, landform position, relative heights, insolation, hydrography and ruggedness. A factor weighting shows that geology, slopes and soils are the most important, respectively. Ruggedness, relative height and insolation have the least weighting, in that order. A weighted sum overlay of the eight factors reveal the variable influence of geology, slope and soils. Geology shows strong influence in the high elevation areas of the western parts of the range. Slope is dominant in the edges, especially the south facing slopes. Soils influence the middle section of the mid slopes.

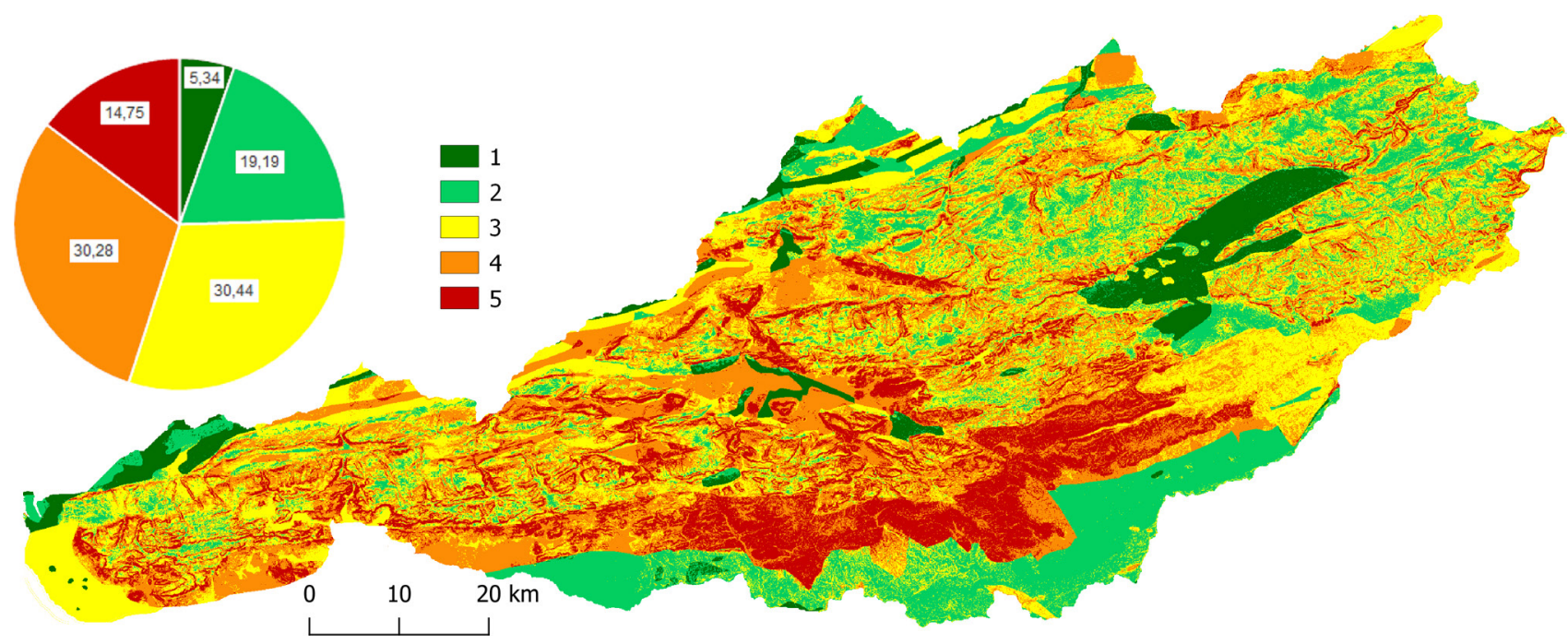

Fig. 11. Soutpansberg geomorphodiversity

1 - very low geodiversity, 2 - low geodiversity, 3 - medium geodiversity, 4 - high geodiversity, 5 - very high geodiversity; the numbers on the pie chart are expressed as a percentage 
We conclude that the Soutpansberg range has significant geomorphological diversity. High and very high geomorphological diversity occupy $45 \%$ of the mountain range. Very low and low geomorphological diversity occupy less than $30 \%$ of the mountain range. Such geomorphological diversity also requires further research focusing on specific factors to promote geo-heritage and geo-education to local communities.

\section{Acknowlegments}

Edmore Kori wish to acknowledge The USDP Programme that funded his attendance in the training during the Geodiversity Workshop in Poland in August 2019. We thank the anonymous reviewers for their careful reading of our manuscript and their many insightful comments and suggestions.

\section{Author's contribution}

EK drafted the paper and did the GIS extractions and calculations. $\mathrm{BDO}$ corrected and commented the paper. HC proofread the paper before initial submission.

\section{References}

Anache J.A.A., Bacchi C.G.V., Panachuki E., Sobrinho T.A., 2015. Assessment of methods for predicting soil erodibility in soil loss modeling. Geociências 34: 32-40.

Araujo A.M., Pereira D.Í., 2018. A new methodological contribution for the geodiversity assessment: applicability to Ceará State (Brazil). Geoheritage 10: 591-605.

Banta R., Cotton W.R., 1981. An Analysis of the structure of local wind systems in a braod mountain basin. Journal of Applied Meteorology 20: 155-1266.

Barry R.G., 2008. Mountain Weather and Climate. Cambridge University Press.

Berger K., Crafford J., Gaigher I., Gaigher M., Hahn N., Macdonald I., 2003. A first synthesis of the environmental, biological and cultural assets of the Soutpansberg. Leach Printers \& Signs, Louis Trichardt, South Africa.

Bouyoucos G.J., 1935. The clay ratio as a criterion of susceptibility of soils to erosion. Journal of the American Society of Agronomy 27: 738-741.

Brandl G., 2003. Geology of the Soutpansberg. In: K.Berger, J.ECrafford, I.Gaigher, M.J.Gaigher, N.Hahn, I.A.W.MacDonald (eds), A first synthesis of the environmental, biological and cultural assets of the Soutpansberg, Louis Tritchardt: 11-13.

Brilha J., Gray M., Pereira D., Pereira P., 2018. Geodiversity: An integrative review as a contribution to the sustainable management of the whole of nature. Environmental Science \& Policy 86: 19-28.

Demek J., Kirchner K., Mackovčin P., Slavík P., 2011. Geomorphodiversity derived by a GIS-based geomorphological map: case study the Czech Republic. Zeitschrift für Geomorphologie 55: 415-435.

Foord S.H., Gelebe V., Prendini L., 2015. Effects of aspect and altitude on scorpion diversity along an environmental gradient in the Soutpansberg, South Africa. Journal of Arid Environments 113: 114-120.

Foord S.H., Mafadza M., Dippenaar-Schoeman A.S., Van Rensburg B., 2008. Micro-scale heterogeneity of spiders (Arachnida: Araneae) in the Soutpansberg, South Africa: a comparative survey and inventory in representative habitats. African Zoology 43: $156-174$.

Gray M., 2004. Geodiversity: valuing and conserving abiotic nature. John Wiley \& Sons.

Gray M., Gordon J. E., Brown E. J., 2013. Geodiversity and the ecosystem approach: the contribution of geoscience in delivering integrated environmental management. Proceedings of the Geologists' Association 124: 659-673.

Grey J.N.C., Bell S., Hill R.A., 2017. Leopard diets and landowner perceptions of human wildlife conflict in the Soutpansberg Mountains, South Africa. Journal for Nature Conservation 37: $56-65$.

Hahn N., 2010. Floristic diversity of the Soutpansberg, Limpopo Province, South Africa. University of Pretoria.

Houshold I., Sharples C., 2008. Geodiversity in the wilderness: a brief history of geoconservation in Tasmania. Geological Society, London, Special Publications 300: 257-272.

Huggett R., 2007. Fundamentals of Geomorphology. Routledge.

Jenks G.F., 1967. The Data Model Concept in Statistical Mapping. International Yearbook of Cartography 7: 186-190.

Jenness J., 2006. Topographic position index (TPI) v. 1.2. Flagstaff, AZ: Jenness Enterprises.

Jerie K., Houshold I., Peters D., 2001. Stream diversity and conservation in Tasmania: yet another new approach. In: Proceedings of the 3rd Australian Stream Management Conference, CRC for Catchment Hydrology: 329-335.

Kabanda T., 2004. Climatology of Long-term Drought in the Nothern Region of the Limpopo Province of South Africa. In: Geography and Geo_Information Sciences. University of Venda: South Africa: University of Venda.

Kabanda T., Munyati C., 2010. Anthropogenic-induced climate change and the resulting tendency towards land conflict: the case of the Soutpansberg region, South Africa. In: D.A.Mwiturubani, J.Van Wy (eds), Climate change and Natural Resources Conflicts in Africa. Pretoria, Monograph 170: 139-155.

Karydas C., Petriolis M., Manakos I., 2013. Evaluating alternative methods of soil erodibility mapping in the Mediterranean Island of Crete. Agriculture 3: 362-380.

Kephe P.N., Petja B.M., Kabanda T.A., 2016. Spatial and inter-seasonal behaviour of rainfall in the Soutpansberg region of South Africa as attributed to the changing climate. Theoretical and applied climatology 126: 233-245.

Kirchhof S., Krämer M., Linden J., Richter K., 2010. The reptile species assemblage of the Soutpansberg (Limpopo Province, South Africa) and its characteristics. Salamandra 46: 147-166.

Marques V.S., Ceddia M.B., Antunes M.A., Carvalho D.F., Anache J.A., Rodrigues D.B., Oliveira P.T.S., 2019. USLE K-Factor Method Selection for a Tropical Catchment. Sustainability 11(7) 1840: 1-17.

Matthews T.J., 2014. Integrating geoconservation and biodiversity conservation: theoretical foundations and conservation recommendations in a European Union context. Geoheritage 6: 57-70.

Melelli L., Vergari F., Liucci L., Del Monte M., 2017. Geomorphodiversity index: Quantifying the diversity of landforms and physical landscape. Science of the Total Environment 584: 701-714.

Milton K., 2002. Loving nature: Towards an ecology of emotion. Psychology Press.

Mostert T. H. C., 2006. Vegetation ecology of the Soutpansberg and Blouberg area in the Limpopo Province. University of Pretoria.

Musila W., Todt H., Uster D., Dalitz H., 2005. Is geodiversity correlated to biodiversity? A case study of the relationship between spatial heterogeneity of soil resources and tree diversity in a Western Kenyan Rainforest. In: B.A.Huber, B.J.Sinclair, K.-H. Lampe (eds), African Biodiversity - Molecules, Organisms, Ecosystems, Springer: 405-414.

Najwer A., Zwoliński Zb., 2014. The landform geodiversity assessment method - a comparative analysis for Polish and Swiss mountainous landscape. IGU 2014 Book of Abstracts, 1201. 
Nenwiinia S., Kabanda T., 2013. Trends and variability assessment of rainfall in Vhembe South Africa. Journal of Human Ecology 42(2): 171-176.

Oettli P., Camberlin P., 2005. Influence of topography on monthly rainfall distribution over East Africa. Climate Research 28: 199-212.

Panizza M., 2009. The geomorphodiversity of the Dolomites (Italy): a key of geoheritage assessment. Geoheritage 1: 33-42.

Peattie R., 2013. Mountain Geography - A Critique and Field Study. Read Books Ltd.

Rodrigues C.V., Palma J.M.L.M., Rodrigues Á.H., 2016. Atmospheric Flow over a Mountainous Region by a One-Way Coupled Approach Based on Reynolds-Averaged Turbulence Modelling. Boundary-Layer Meteorol 159: 407-437.

Sharples C., 1993. A methodology for the identification of significant landforms and geological sites for geoconservation purposes. Forestry Commission, Tasmania: 3-31.

Sharples C., 1995. Geoconservation in forest management - principles and procedures. Tasforest 7: 37-50.

Sharples C., McIntosh P., Comfort M., 2018. Geodiversity and Geoconservation in Land Management in Tasmania - A Top-Down Approach. In: E.Reynard, J.Brihla (eds), Geoheritage Assessment, Protection, and Management, Elsevier: 355-371.

Smith R.B., 2007. Interacting mountain waves and boundary layers. Journal of the Atmospheric Sciences 64: 594-607.

Stoelinga M.T., Stewart R.E., Thompson G., Thériault J.M., 2013. Microphysical Processes within Winter Orographic Cloud and Precipitation Systems. F.K.Chow, S.F.J.De Wekker, B.J.Snyder (eds), Mountain Weather Research and Forecasting: Recent Progress and Current Challenges,, Springer: 345-408.
Sun W.-Y., Sun O.M., 2015. Bernoulli equation and flow over a mountain. Geoscience Letters 2-7.

Taylor P.J., Sowler S., Schoeman M.C., Monadjem A., 2013. Diversity of bats in the Soutpansberg and Blouberg Mountains of northern South Africa: complementarity of acoustic and non-acoustic survey methods. African Journal of Wildlife Research 43: $12-26$.

Thomas M., 2012. A geomorphological approach to geodiversity - its applications to geoconservation and geotourism. Quaestiones Geographicae 31: 81-89.

Uzun O., Kaplan S., Basaran M., Deviren Saygin S., Youssef F., Nouri A., Ozcan A. U., Erpul G., 2017. Spatial distribution of wind-driven sediment transport rate in a fallow plot in Central Anatolia, Turkey. Arid Land Research and Management 31: 125-139.

Wischmeier W.H., Smith D.D., 1978. Predicting Rainfall Erosion Losses: A Guide to Conservation Planning. Agriculture Handbook No. 537. USDA/Science and Education Administration, US. Govt. Printing Office, Washington (DC): 1-58.

Zardi D., Whiteman C.D., 2013. Diurnal Mountain Wind Systems. In: F.K.Chow, S.F.J.De Wekker, B.J.Snyder (eds), Mountain Weather Research and Forecasting: Recent Progress and Current Challenges, Springer: $35-119$.

Zwoliński Zb., 2004. Geodiversity. In: A.S.Goudie (ed), Encyclopedia of Geomorphology, 1. Routledge: 417-418.

Zwoliński Zb., 2009. The routine of landform geodiversity map design for the Polish Carpathian Mts. Landform Analysis 11: 77-85.

Zwoliński Zb., Najwer A., Giardino M., 2018. Methods for assessing geodiversity. In: E.Reynard, J.Brihla (eds), Geoheritage Assessment, Protection, and Management, Elsevier: 27-52. 